\title{
KÜLSZÍNI BÁNYÁSZATI ROBBANTÁSOK SZEIZMIKUS HATÁSA AZ ERDÖBÉNYEI ANDEZITBÁNYÁBAN
}

\author{
Szarvas Beáta \\ Ph.D. hallgató, Miskolci Egyetem, Bányászati és Geotechnikai Intézet, \\ 3515 Miskolc-Egyetemváros, e-mail: beata.szarvas@uni-miskolc.hu \\ Virág Zoltán \\ egyetemi docens, Miskolci Egyetem, Bányászati és Geotechnikai Intézet, \\ 3515 Miskolc-Egyetemváros, e-mail: zoltan.virag@uni-miskolc.hu
}

\begin{abstract}
Absztrakt
A bányászati célú robbantások egyik kiséröjelensége a közetben terjedő szeizmikus hatás. Ennek mértéke befolyásolható különbözö megoldásokkal, igy káros hatása elkerülhetö, de a jelenlétével mindig számolni kell. A rezgések nagyságát geofonnal mérhetjük, amit a hatósági elöirások évente egyszer kötelezövé is tesznek a bányaüzem számára. Egy kiválasztott köbányához közeli lakott területen végzett korábbi szeizmikus ellenörzö mérések eredményei kerülnek bemutatásra. A mért értékeket összehasonlítjuk a robbantásokkor és a jelenleg érvényes szabályzatok elöírásaival.
\end{abstract}

Kulcsszavak: bányászat, robbantás, szeizmikus hatás, rezgésmérés

\begin{abstract}
One of the side effects of blasting is the seismic effect propagating in the rock. The extent of this can be influenced by different solutions, so its harmful effects can be avoided, but its presence must always be taken into account. The magnitude of the vibrations can be measured with a geophone, which is also made mandatory for the mining operation by the official regulations once a year. The results of previous seismic monitoring measurements in a residential area near a selected quarry are presented. The measured values are compared with the requirements of the current and previous regulations.
\end{abstract}

Keywords: mining, blasting, seismic effect, vibration measurement

\section{Bevezetés}

A bányászat egyidős az emberiség történetével. A technikai fejlődéssel mindig is egyre nagyobb szükség mutatkozott a különböző nyersanyagokra, amelyeket a Föld kérge rejt. Ezek az ásványi anyagok többféleképpen kitermelhetőek. Azt, hogy ezek közül a művelési módszerek közül melyik a leggazdaságosabb, a telepviszonyok, a telep és a fedőkőzetek minősége, a meglévő és az egyes müvelési technológiákhoz kiépítendő infrastruktúra és egyéb gazdasági tényezők együttes figyelembevételével határozhatjuk meg.

A külfejtésesek szilárd kőzeteinek jövesztése nagyrészt robbantással történik. Az itt alkalmazott robbantástechnológiák célja, hogy a lejövesztett készletet rakodásra, szállításra és további feldolgozásra alkalmas legyen. A robbantáskor létrehozott energiának általában a nagyobb része azonban nem kedvező a felhasználó számára. A káros környezeti hatások közül a szeizmikus hatás az egyik legjobban 
mérhető. A rezgések hatásai nem olyan látványosak, mint a repeszhatásból és léglökésből keletkezők, azonban környezetterhelése túlnyúlik a bányatelek határán. A bánya környezetében levő idegen tulajdonú létesítmények védelme természetes és kötelező feladata a bánya üzemeltetőjének. A robbantások tervezése, a bánya felelös irányítása és a környezet védelme megköveteli mind a bányavállalkozótól, mind a robbantásvezetőtől, hogy kellő pontossággal ismerje a bánya és környezete szeizmikus viszonyait. A tervező a robbantási szabályzatokban előírt módon előre megbecsülheti a várható rezgést, hogy az ne haladja meg a megengedett értéket a védendő létesítményeknél. A bányavállalkozóknak célszerü lenne nagyrobbantások alkalmával a robbantások okozta rezgéseket rendszeresen mérnie, amelyeket a hatósági elöírások évente egyszer kötelezővé is tesznek egy független ellenőrző vizsgálati mérés által. Ezek meglétével kivédhetők a bányaüzem robbantásaival kapcsolatos panaszos bejelentések (Bohus et al., 1983; Bohus, Boócz, 2006).

Az alábbiakban egy kiválasztott kőbányához közeli lakott területen végzett szeizmikus ellenőrző mérések eredményei kerülnek bemutatásra. A mért értékeket összehasonlítjuk a robbantásokkor és a jelenleg érvényes Általános Robbantási Biztonsági Szabályzat elöírásaival (9/1987 (Bh. É. 3.) OBF számú szabályzata; MSZ 13018:1991; 13/2010. (III. 4.) KHEM rendelet).

\section{Az erdőbényei bányában végzett robbantások}

Erdőbényén az andezitet csak a múlt század elején kezdték el bányászni a Mulató-hegyen, a Hubertuszbányában. Az 1925-ben megnyitott bányában, kezdetben kézi módszerrel, majd robbantásos technikával fejtettek. Az itt és a szomszédos Barnamáj hegyen bányászott sötétszürke ép andezitet a helyszínen különböző szemnagyságúra összezúzták és útkavicsolásra, vasúti töltések készítésére, javítására használták. A kitermelt nyersanyag kisebb-nagyobb tömbjei építkezési célokat is szolgáltak. A Hubertusz köfejtő a megfelelő kőanyag csökkenése, illetve vízproblémák miatt 1983-ban bezárt. Sokáig felhagyva állt, majd a 2000-es években újra müvelték (2007-ig), azóta a komolyabb bányászati tevékenység újra leállt, jelenleg csak néha hordanak el meddőt útfeltöltésekre, mederigazításokra (wikipedia.org: Mulatóhegy). A tanulmány adatait az „Erdőbénye-V.-Andezit” védjegyü bányatelken (1. ábra) 2006-2007. években végzett robbantási munkákhoz kapcsolódó mérési adatok szolgáltatták.

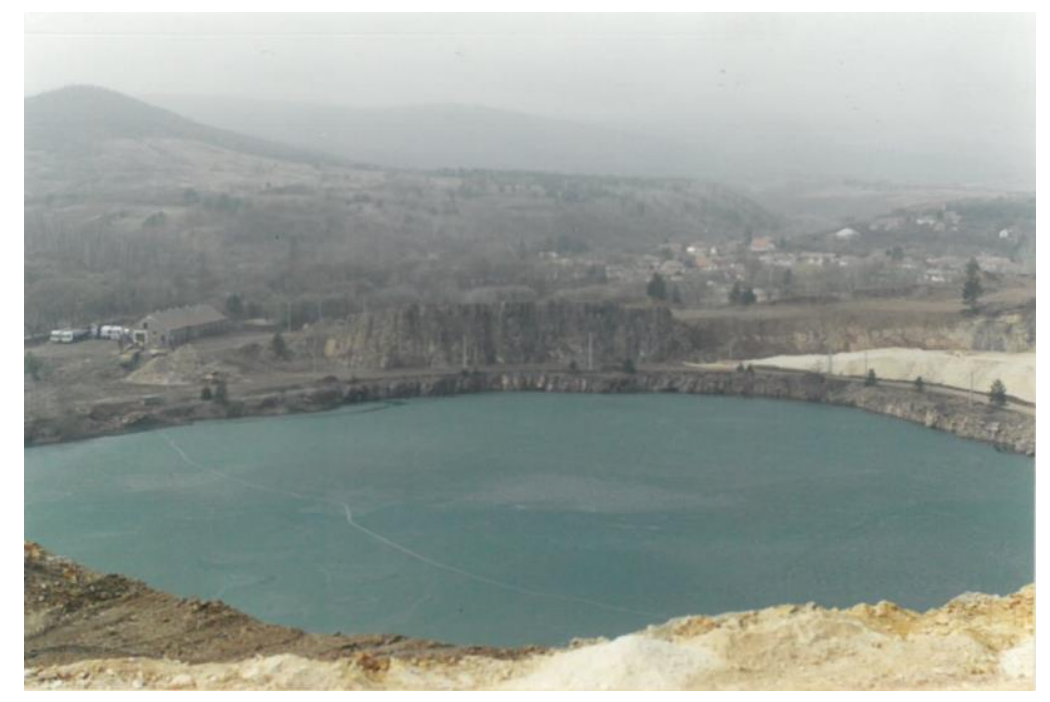

1. ábra. Az erdöbényei andezitbánya látképe (Bohus Géza, 2007) 
Ezen a helyen rövid időn belül hasonló technológiával végzett robbantások voltak, melyek által keltett rezgéseket azonos helyeken mérték. Ez a körülmény lehetőséget adott arra, hogy bizonyítsuk a szabályzatok (kötelező előírások) használhatóságát.

A vizsgált külszíni bányászati célú robbantásokat az erdőbényei kőbánya keleti és nyugati oldalán hajtották végre. Minden robbantásnál ANDO típusú robbanóanyagot használtak EMULGIT indítótöltényekkel. A robbantás indítására alkalmazott villamos gyutacsok DeM típusúak voltak. A szeizmikus mérések - az előírásoknak megfelelően - a robbantási munkákhoz legközelebb fekvő lakóháznál történtek. Jelen tanulmányban az összehasonlíthatóság okán kizárólag a vizsgálatsorozat azon mérési eredményeit vettük figyelembe, amelyek egyazon épületnél lettek mérve, a közel azonos távolságban és irányban végrehajtott robbantások során.

\section{A vizsgált robbantások szeizmikus hatásaira vonatkozó szabályok}

A szeizmikus rezgések kárhatásaira vonatkozó előírások, szabványok és szabályzatok (hazai és külföldi) kitérnek arra, hogy a károk kialakulásának előre becsülhető valószínüsége van. Ezek általában kimondják, hogy ha a rezgések a még megengedett legnagyobb rezgési sebességet nem haladják meg, akkor a kárhatás valószínüsége olyan kicsi, hogy a kár gyakorlatilag nem következik be. Ha a rezgési sebesség ezt az értéket meghaladja a kár valószínüsége nő, mely növekedés annál nagyobb, minél nagyobb a rezgési sebesség eltérése a még megengedett legnagyobb rezgési sebességtöl.

A robbantások szeizmikus hatásaira vonatkozó szabályokat a robbantások idején érvényben lévő 9/1987 (Bh. É. 3.) OBF számú szabályzata a 2/1973. (NIM. É. 16.) OBF számú utasítással kiadott Általános Robbantási Biztonsági Szabályzat módosításáról (továbbiakban ÁRBSZ 1987) szóló rendelkezés III. függelék B. része (Bohus et al., 1983), a MSZ 13018:1991 Rezgések épületre gyakorolt hatása szabvány (továbbiakban MSZ 13018) 1. számú táblázata (Bohus, Boócz, 2006) és a napjainkban hatályos 13/2010. (III. 4.) KHEM rendelet az Általános Robbantási Biztonsági Szabályzatról (továbbiakban (ÁRBSZ2010) 4. melléklete (9/1987 (Bh. É. 3.) OBF számúszabályzat) tartalmazza. Alábbiakban öszszegyűjtésre kerülnek a vizsgált robbantásokra vonatkozó előírások.

\section{1. ÁRBSZ 1987 vonatkozó előírásai}

A rendelet (9/1987 (Bh. É. 3.) OBF számúszabályzat) alapján a szeizmikus biztonsági távolságot az alábbi képlettel kell meghatározni

$$
L=k \sqrt{Q}
$$

ahol

- $\quad L(\mathrm{~m})$ - a szeizmikus biztonsági távolság,

- $Q(\mathrm{~kg})-$ az egyidejủleg robbanó töltet tömege,

- $\quad k$ - tényezö értéke:

a) víz alatt vagy mocsaras talajban tervezett robbantásnál 100,

b) egy éven belül ötnél többször ismétlődő robbantás esetén 50 ,

c) egyedi robbantás esetén 25 ,

d) rátett töltet és áthalmozott anyag terítése esetén 5 .

A robbantások várható rezgési sebességének meghatározására szolgáló számítás, amennyiben a szeizmikus biztonsági távolságon belül védendő létesítmény van:

$$
V=\frac{k \sqrt{Q}}{l}
$$


ahol

- $\quad V(\mathrm{~mm} / \mathrm{s})$ - az a rezgési sebesség, amelynél nagyobb nem várható $l$ távolságban,

- $\quad l(\mathrm{~m})$ - az egyidejüleg robbanó töltet tömegközéppontjától a megvédendő létesítménynek a legközelebbi talajfelszíni pontjáig mért - a magasságkülönbséget is figyelembe vevő - távolság.

1. táblázat. A robbantásnál megengedett rezgési sebességek épületkategóriánként

\begin{tabular}{|c|c|}
\hline A megvédendő létesítmény megnevezése & $\begin{array}{l}\text { Megengedett legnagyobb } \\
\text { rezgési sebesség } \\
\mathbf{v}[\mathrm{mm} / \mathrm{s}]\end{array}$ \\
\hline Különleges védelmet igénylő létesítmények & szakértői vélemény szerint \\
\hline $\begin{array}{l}\text { Statikailag bizonytalan, megrongálódott építmény, } \\
\text { müemlék, termelő kőolaj- és földgázkút, valamint } \\
0,17 \text { MPa-nál nagyobb és } 0,07 \text { MPa-nál kisebb nyo- } \\
\text { más alatt álló csővezeték és szerelvény }\end{array}$ & 2 \\
\hline Panelház és statikailag nem teljes értékü építmény & 5 \\
\hline $\begin{array}{l}\text { Statikailag kifogástalan építmény, torony, gyárké- } \\
\text { mény, villamos és vízmü szabadtéri villamos beren- } \\
\text { dezés }\end{array}$ & 10 \\
\hline $\begin{array}{l}\text { Vasbeton vagy acélvázas építmény, alagút, } 0,7 \text { m- } \\
\text { nél mélyebben vezetett csatorna és egyéb csőveze- } \\
\text { ték, valamint szerelvény, föld alatti térség }\end{array}$ & 20 \\
\hline $\begin{array}{l}\text { Közút, vasút, függőpálya, villamos távvezeték, táv- } \\
\text { beszélővezeték }\end{array}$ & 50 \\
\hline
\end{tabular}

A szabályzat épületkategóriánként határozza meg az azokat terhelhető maximális rezgési sebességeket. A 200 m-nél nagyobb távolságban végzett robbantások esetén a rezgési sebességek fele engedhető meg minden olyan építményre, amelynek magassága meghaladja a $20 \mathrm{~m}$-t, és magasabb a hosszabbik alapélénél.

\subsection{Az MSZ 13018 szabvány robbantás keltette rezgésekre vonatkozó előírásai}

A napjainkban is érvényes szabvány (MSZ 13018:1991) átmeneti folyamatok okozta rövid idejű rezgésekre, amelyek idővel vagy megszünnek, vagy átmennek nem rövid idejü rezgésekbe és időtartamuk alapján nem okozhatnak kifáradást, a rövid idejü épületrezgések megítéléséhez, épületkategóriánként és frekvencia tartományonként tapasztalati értékekéböl határozza meg az épület alapnál x, y vagy z irányban fellépő rezgéssebesség megengedett irányértékeit, amelyek a 2. számú táblázatban kerültek összefoglalásra. Többszintes épületek vizsgálatakor további irányértékekkel szolgál a legfelső teljes szint födémsíkjában az épület vízszintes irányú rezgéseinek. A 2. ábra grafikusan is szemlélteti a 2. táblázat adatait a frekvencia függvényében. 
2. táblázat. A megengedett rezgési sebességek épület fajtánként

\begin{tabular}{|c|c|c|c|c|c|c|}
\hline \multirow{3}{*}{$\begin{array}{l}\text { Sor- } \\
\text { szám }\end{array}$} & \multirow{3}{*}{ Épületfajta } & \multicolumn{5}{|c|}{ Megengedett rezgési sebesség [mm/s] } \\
\hline & & \multicolumn{4}{|c|}{$\begin{array}{c}\text { Az alapokon különbözö } \\
\text { frekvenciánál }\end{array}$} & \multirow{2}{*}{$\begin{array}{l}\text { A legfelsó teljes szint fö- } \\
\text { démsíkjában, vízszinte- } \\
\text { sen bármely frekvencián }\end{array}$} \\
\hline & & $\mathbf{0 ~ H z}$ & $10 \mathrm{~Hz}$ & $50 \mathrm{~Hz}$ & $100 \mathrm{~Hz}$ & \\
\hline 1 & Ipari területek & 20 & 20 & 40 & 50 & 40 \\
\hline 2 & Lakóépületek & 5 & 5 & 15 & 20 & 15 \\
\hline 3 & $\begin{array}{l}\text { Különösen rezgés- } \\
\text { érzékeny épületek } \\
\text { (pl.: múemlék) }\end{array}$ & 3 & 3 & 8 & 10 & 8 \\
\hline 4 & $\begin{array}{l}\text { Statikailag bizony- } \\
\text { talan; építési előírá- } \\
\text { soknak meg nem fe- } \\
\text { lelő épületek }\end{array}$ & \multicolumn{5}{|c|}{ Szakértői mérlegelés szerint } \\
\hline
\end{tabular}

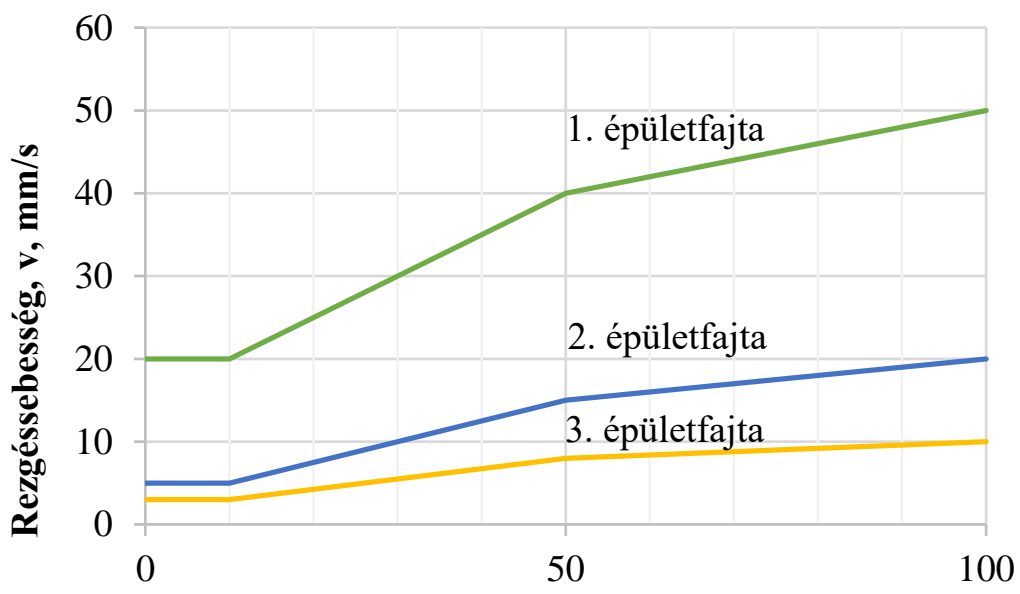

Frekvencia, Hz

2. ábra. Az alapon fellépö rezgéseknek a 2. táblázat szerint megengedett irányértékei

\subsection{A jelenleg érvényes ÁRBSZ 2010 vonatkozó részei}

A jelenleg érvényes rendelet (13/2010. (III. 4.) KHEM rendelet) szerint a szeizmikus biztonsági távolságot - ami nem jelenti azonban az épületkárok feltétlen fellépését e távolságon belül - az alábbi képlettel vagy szakértői véleményben kell meghatározni:

$$
L=\frac{K}{2} \sqrt{Q_{f}}
$$


ahol,

- $\quad L(\mathrm{~m})$ - a szeizmikus biztonsági távolság

- $\quad K$ - tényező, amelynek értéke:

a) víz alatt vagy mocsaras talajban végzett robbantásnál, és 10 m-nél vastagabb agyagrétegre épült objektumokra 160 ,

b) rendszeresen ismétlődő, elöre kijelölt, viszonylag szük körzetben, elsősorban termelési céllal végzett robbantás esetében 80 ,

c) egyedi, konkrét feladat megoldására vagy jelentősen változó területen végzett robbantás esetében 40 ,

d) rátett töltet alkalmazása és áthalmozott anyag terítése esetén 20 .

- $Q_{f}(\mathrm{~kg})$ - a mértékadó töltet (gyutacs használata esetén az azonos névleges időzítési intervallumokban robbantott töltetek közül a legnagyobb; gyújtózsinór használata esetén a legnagyobb töltet kétszerese; nyújtott töltet esetén a 20 méter hosszú töltet tömege)

A várható rezgési sebesség értékét a következő képlet segítségével kell meghatározni:

$$
v=\frac{K \sqrt{Q_{f}}}{l}
$$

ahol

- $\quad l(m)$ - a mértékadó töltet tömegközéppontjától a megvédendő létesítmény legközelebbi pontjáig mért - a magasságkülönbséget is figyelembe vevő - távolság,

- $\quad v(\mathrm{~mm} / \mathrm{s})$ - a rezgési sebesség, amelynél nagyobb nem várható $l$ távolságban.

3. táblázat. A megvédendö létesitmény besorolása

\begin{tabular}{|c|c|c|}
\hline & A & $\mathrm{B}$ \\
\hline 1. & Megnevezés & Kategória \\
\hline 2. & Különleges védelmet igénylő létesítmények & \multirow{5}{*}{ I. } \\
\hline 3. & 25 m-nél nagyobb fesztávú építmény & \\
\hline 4. & Statikailag bizonytalan, megrongálódott építmények & \\
\hline 5. & Műemlék & \\
\hline 6. & $\begin{array}{l}\text { Termelö kőolaj- és földgázkút, valamint } 0,017 \text { MPa-nál nagyobb és } 0,07 \\
\text { MPa-nál kisebb nyomás alatt álló csővezeték és szerelvény }\end{array}$ & \\
\hline 7. & Tízszintesnél magasabb épület & \multirow{2}{*}{ II. } \\
\hline 8. & Rádió- és TV-adótorony & \\
\hline 9. & $\begin{array}{l}\text { Ép, jó állapotú építmény, torony, gyárkémény, villamos berendezés, táv- } \\
\text { beszélő vezeték }\end{array}$ & III. \\
\hline 10. & Vasbeton- vagy acélvázas építmény & \multirow{4}{*}{ IV. } \\
\hline 11. & Alagút & \\
\hline 12. & $\begin{array}{l}0,8 \text { m-nél mélyebben vezetett csatorna és egyéb csővezeték, valamint } \\
\text { szerelvény és egyéb föld alatti térség }\end{array}$ & \\
\hline 13. & Vasút, közút, függőpálya, villamos távvezeték & \\
\hline
\end{tabular}


A számított rezgési sebesség megfelelö, ha a rendeletben foglalt képlettel meghatározott rezgési sebesség $v(\mathrm{~mm} / \mathrm{s})$ értéke kisebb az 3. ábrán leolvasott értéknél, figyelemmel a megvédendő létesítmény besorolására (3. táblázat).

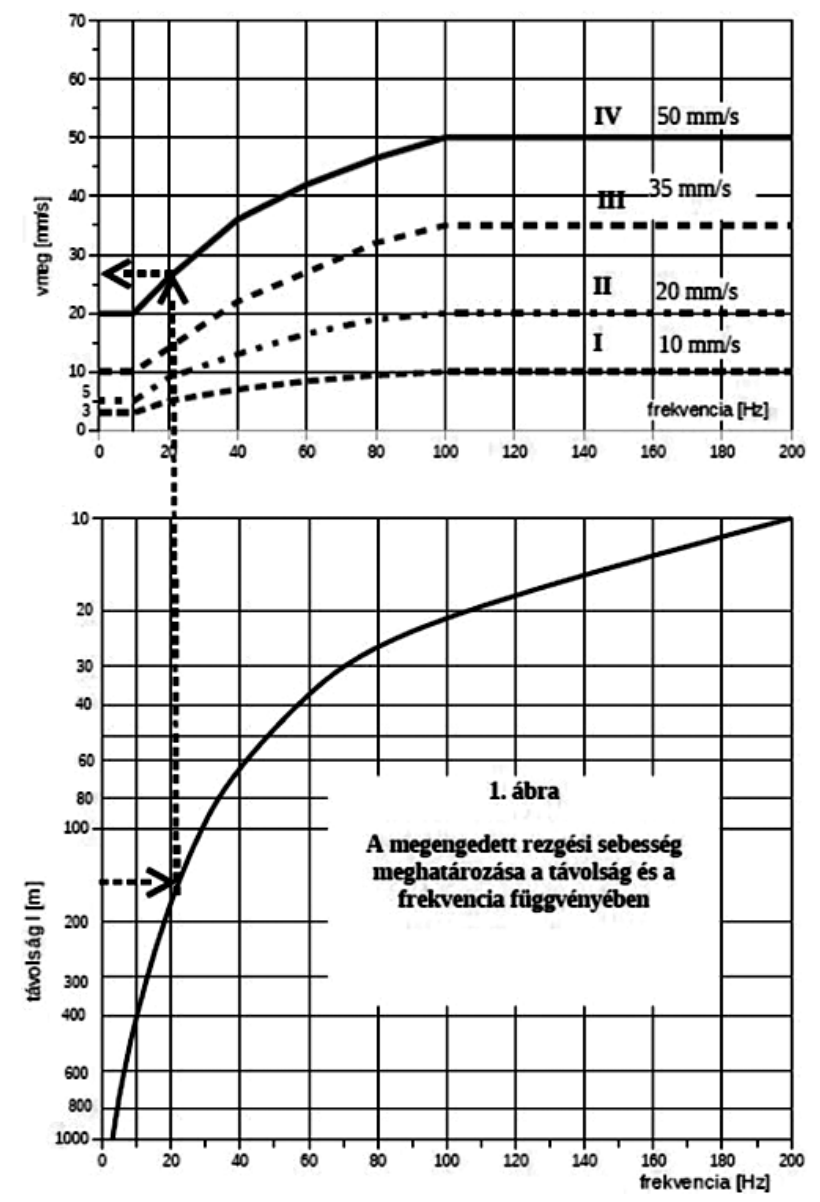

3. ábra. A megengedett rezgési sebesség meghatározása a távolság és a frekvencia függvényében

\section{A szeizmikus mérés ismertetése}

A méréshez a GeoPolita Kft. által készített GP-MF94VB hordozható számítógépes adatgyüjtővel ellátott rezgésmérő és feldolgozó rendszert használtak. A rendszer 5 darab három dimenziós mérőpontban $(\mathrm{x}, \mathrm{y}, \mathrm{z})$ történő mérésre alkalmas. A geofonok a tér három irányának $(\mathrm{x}, \mathrm{y}, \mathrm{z})$ megfelelően mérik a rezgési gyorsulást és képezik a rezgési sebességet irányonként, valamint az eredő rezgési sebesség értékét.

A rendszer részei (4. ábra):

- központi mérő-feldolgozó egység (486/33 notebook számítógép),

- piezoelektromos érzékelö,

- kábelek,

- központi elosztódoboz, 
- helyi elosztódobozok,

- érzékelötartó kockák,

- hord táskák.

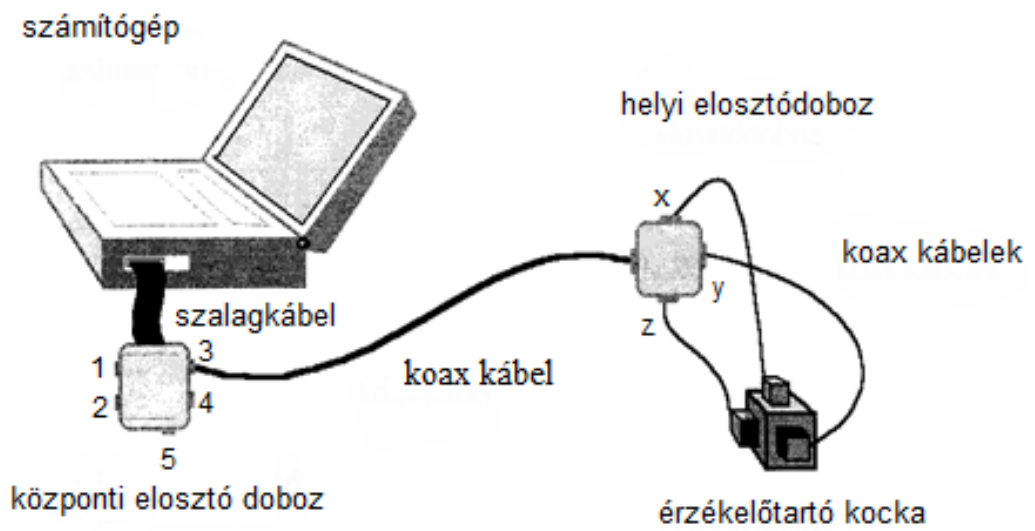

4. ábra. A szeizmikus méröberendezés részei [7]

A rezgésmérő geofon-csoportokat a bányához legközelebbi háznál 5 ponton helyezték el. Az 5 . ábra szemlélteti a vizsgált robbantások (1-5.) valamint a mérések helyszínét. Látható, hogy az 1. robbantási hely és a szeizmikus mérési helyszín közre fogja a vízzel telt bányagödröt.
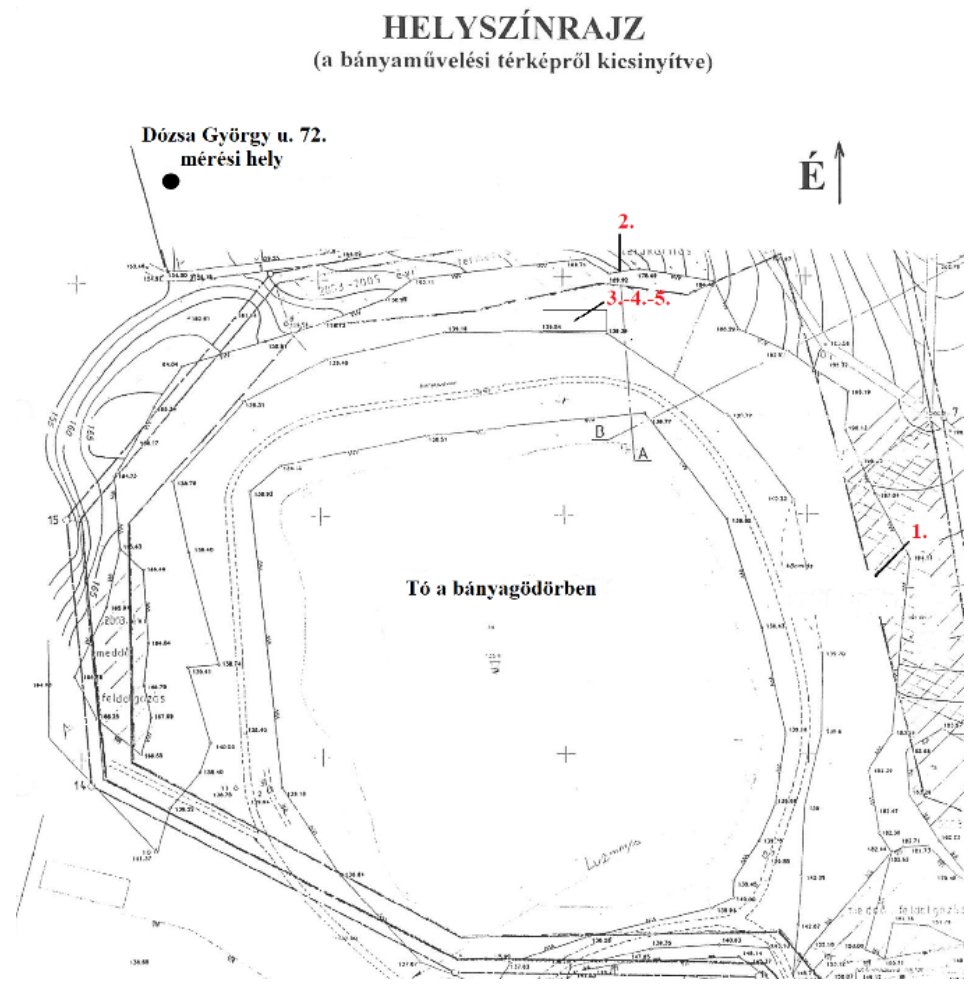

5. ábra. A mérések elhelyezkedése (1.-5. pontok a robbantások helyszinei) 
Szabályzat szerint a robbantás irányába mutató ’x’ komponens került értékelésre (6. ábra).

$$
x
$$

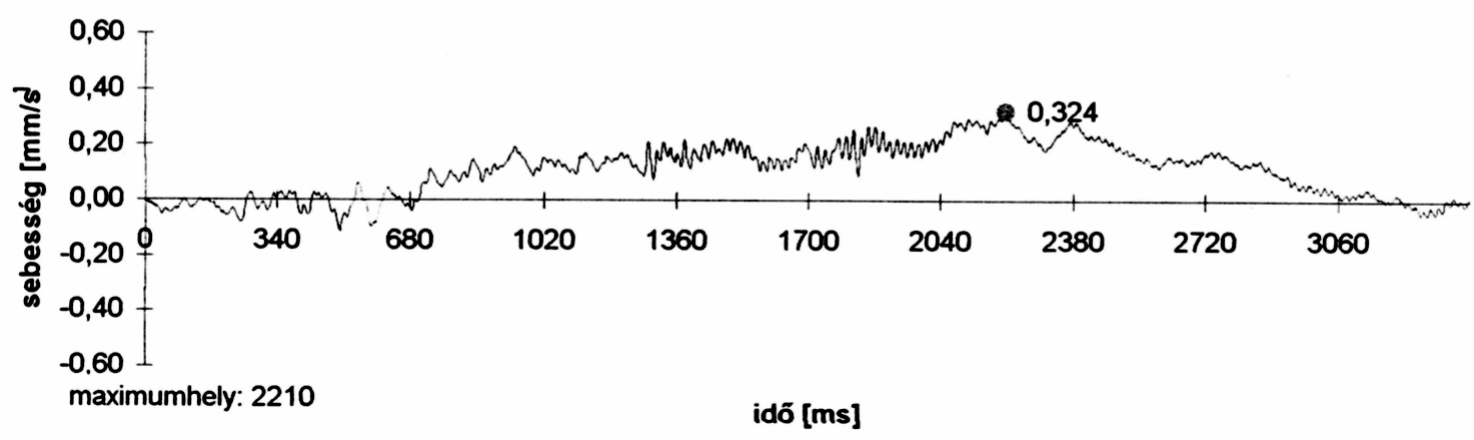

6. ábra. Egy a bányára jellemző robbantási szeizmogram

\section{A mérési eredmények összegzése}

A vizsgálat során használt elöírások közötti különbség abban mutatkozik meg, hogy a mért három egymásra meröleges rezgési sebesség komponens között az ÁRBSZ rendeletek a robbantás irányába mutató $\left(v_{x}\right)$, az MSZ13018 szabvány pedig biztonsági okokból a legnagyobb értékủ sebességkomponenst veszi figyelembe $\left(v_{\max }\right)$. A robbantások paramétereit a 4 . táblázat, a mérések eredményeit az 5 . táblázat foglalja össze (Bohus, Boócz, 2006-2007), ahol minden megfigyelt robbantási munkánál az öt mérési pontból a robbantás helyéhez legközelebbit és az ahhoz tartozó legnagyobb rezgési sebességeket vettük figyelembe. Az 5. táblázatban kiszámításra kerültek továbbá a robbantás szeizmikus hatását jellemző $k$ tényezők és a mért rezgési sebességek ( $v_{\max }$ és $v_{x \max }$ ).

4. táblázat. A robbantások paraméterei

\begin{tabular}{|c|l|c|c|c|}
\hline Sorszám & $\begin{array}{c}\text { A robbantás } \\
\text { ideje }\end{array}$ & $\begin{array}{c}\text { A robbantás és } \\
\text { a mérési pont } \\
\text { távolsága } \\
\mathbf{I}[\mathbf{m}]\end{array}$ & $\begin{array}{c}\text { Mértékadó } \\
\text { töltetnagyság } \\
\mathbf{Q}[\mathbf{l k g}]\end{array}$ & $\begin{array}{c}\text { Összesen felhasznált } \\
\text { robbanóanyag } \\
\text { mennyisége } \\
\sum \mathbf{Q}[\mathbf{k g}]\end{array}$ \\
\hline 1. & 2006. március & 410 & 85 & 418 \\
\hline 2. & 2006. július & 180 & 40 & 305 \\
\hline 3. & 2006. november & 220 & 90 & 590 \\
\hline 4. & 2007. április & 190 & 45 & 339 \\
\hline 5. & 2007. augusztus & 225 & 37 & 29,5 \\
\hline \hline \multicolumn{2}{|c|}{ Átlagérték } & 245 & 59 & 336 \\
\hline
\end{tabular}


5. táblázat. A robbantások mérési eredményei

\begin{tabular}{|c|c|c|c|}
\hline Sorszám & $\begin{array}{c}\text { Maximális } \mathbf{x} \text { irányú } \\
\text { rezgési } \\
\text { sebesség-komponens } \\
\mathbf{v}_{\mathbf{x m a x}}[\mathbf{m m} / \mathbf{s}]\end{array}$ & $\begin{array}{c}\text { Maximális rez- } \\
\text { gési sebesség } \\
\mathbf{v}_{\text {max }}[\mathbf{m m} / \mathbf{s}]\end{array}$ & $\begin{array}{c}\text { A robbantás szeizmikus } \\
\text { hatását jellemző k tényező } \\
\text { értéke }\end{array}$ \\
$\boldsymbol{k}=\boldsymbol{v}_{\boldsymbol{x m a x}} \frac{\boldsymbol{l}}{\sqrt{\boldsymbol{Q}}}$ \\
\hline 1. & 0,39 & 0,304 & 17 \\
\hline 2. & 0,95 & 0,95 & 27 \\
\hline 3. & 0,85 & 3,447 & 20 \\
\hline 4. & 1,53 & 1,53 & 43 \\
\hline 5. & 0,74 & 1,824 & 27 \\
\hline \hline Átlagérték & 0,89 & 1,611 & 27 \\
\hline
\end{tabular}

A 6. táblázatban kiszámításra kerültek a vizsgált robbantásokra vonatkozó várható rezgési sebességek, az akkori és a jelenleg hatályban lévő szabályzatok elöírásainak megfelelően.

6. táblázat. A robbantások adott szabályzat szerinti várható rezgési sebességei

\begin{tabular}{|c|c|c|c|c|}
\hline \multirow{2}{*}{ Sorszám } & \multicolumn{2}{|c|}{$k$ V tényezó } & \multicolumn{2}{c|}{ Várható rezgési sebesség } \\
& \multicolumn{2}{|c|}{} & & \\
\cline { 2 - 5 } & Ám/s] \\
\hline 1. & 50 & 80 & 1,53 & 2,44 \\
\hline 2. & 50 & 80 & 1,76 & 2,81 \\
\hline 3. & 50 & 80 & 2,16 & 3,45 \\
\hline 4. & 50 & 80 & 1,76 & 2,82 \\
\hline 5. & 50 & 80 & 1,35 & 2,16 \\
\hline \hline Átlagérték & 50 & 80 & 1,71 & 2,74 \\
\hline
\end{tabular}

A 7. táblázatban meghatározásra kerültek a mérési ponton elhelyezkedő építményre megengedett maximális rezgési sebesség értékek adott körülmények között az MSZ13018 szabvány és az ÁRBSZ 2010 iránymutatásai alapján.

\section{6. Összefoglalás}

A bányászati célú robbantások egyik kisérőjelensége a kőzetben terjedő szeizmikus hatás. A bánya környezetében levő idegen tulajdonú létesítmények védelme érdekében a bányavállalkozóknak célszerü a nagyrobbantások alkalmával a robbantások okozta rezgéseket rendszeresen mérnie. Ezt az egyik legjobban mérhető káros hatást kell az érvényes szabályzatok elöírásaival összevetni. 
Jelen tanulmányban vizsgált korábbi robbantások eredményeiből megállapítható, hogy azok szeizmikus hatását jellemző $k$ tényező számított értéke $17<k<43$ (átlagosan 27), kisebb, mint a kőbányai robbantásoknál akkor érvényes elóírások által meghatározott $k=50$ érték, és messze elmarad a napjainkban érvényben szabályzat által meghatározott $k=80$ értékhez képest. Ebből jól látható, hogy a mérésekor alkalmazott robbantástechnológia az adott környezetben kisebb rezgéseket idézett elö, mint az átlagos körülmények között várható. Ez a körülmény arra is enged következtetni, hogy az erdőbényei andezit bánya környezete szeizmikusan nem túl érzékeny.

7. táblázat. A robbantások adott szabályzat szerinti megengedett rezgési sebességei

\begin{tabular}{|c|c|c|c|c|}
\hline \multirow{2}{*}{$\begin{array}{l}\text { Sor- } \\
\text { szám }\end{array}$} & \multirow{2}{*}{$\begin{array}{l}\text { A rezgések } \\
\text { jellemző frek- } \\
\text { venciája } \\
\text { f [Hz] }\end{array}$} & \multirow{2}{*}{$\begin{array}{l}\text { Megengedett rez- } \\
\text { gési sebesség la- } \\
\text { kóépületre } \\
\mathrm{v}_{\mathrm{sz}}[\mathrm{mm} / \mathrm{s}] \\
\text { MSZ } 13018 \text { szab- } \\
\text { vány }\end{array}$} & \multicolumn{2}{|c|}{$\begin{array}{c}\text { Megengedett rezgési sebesség } \\
\text { (ÁRBSZ 2010) } \\
\text { v [mm/s] }\end{array}$} \\
\hline & & & $\begin{array}{l}\text { Statikailag bizonytalan } \\
\text { építmény (I. kategória) }\end{array}$ & $\begin{array}{l}\text { Ép, jó állapotú építmény } \\
\text { (III. kategória) }\end{array}$ \\
\hline 1. & $10-20$ & 5 & $3-5$ & $10-20$ \\
\hline 2. & $10-20$ & 5 & $3-5$ & $10-20$ \\
\hline 3. & $39-47$ & $15-20$ & $6-8$ & $22-23$ \\
\hline 4. & $26-61$ & $5-15$ & $5-9$ & $20-27$ \\
\hline 5. & $14-52$ & $5-15$ & $3-6$ & $10-25$ \\
\hline
\end{tabular}

A vizsgálat másik szemszögéből a mért x irányú sebességkomponensek maximális értékei lényegesen alacsonyabbak a szabályzatok által meghatározott megengedett sebességértékeknél, ezért a legközelebbi védett objektumoknál nem kell számítani a bányászati célú robbantásokból adódó károsító hatásra.

\section{Irodalom}

[1] Bohus, G., Horváth, L., Papp, J. (1983). Ipari robbantástechnika. Műszaki Kiadó, Budapest.

[2] Bohus, G., Boócz, Z. (2006). Egy lakott településhez közeli kőbányában végzett robbantások szeizmikus hatásának vizsgálata. A Miskolci Egyetem Közleménye A sorozat, Bányászat, 68, 6376. https://doi.org/10.1007/BF02960855

[3] 9/1987 (Bh. É. 3.) OBF számú szabályzata a 2/1973. (NIM. É. 16.) OBF számú utasitással kiadott Általános Robbantási Biztonsági Szabályzat módosításáról, Bányahatósági Értesítő 1987. november, Hírlapkiadó, Budapest, 1987.

[4] MSZ 13018:1991 Rezgések épületre gyakorolt hatása, Magyar Szabvány, 1991.

[5] 13/2010. (III. 4.) KHEM rendelet az Általános Robbantási Biztonsági Szabályzatról, Magyar Közlöny 31. szám, 9762-9829. o., Magyar Közlöny Lap- és Könyvkiadó, Budapest, 2010.

[6] https://hu.wikipedia.org/wiki/Mulató-hegy, 2021.10.26.

[7] Bohus, G., Boócz, Z. (2006-2007). Jegyzökönyv az erdőbényei andezitbányában végzett robbantások szeizmikus ellenőrzö méréseiről. ME Bányászati és Geotechnikai Tanszék tanszéki kutatómunkák, Miskolci Egyetem. 